\title{
Usage of P/E earning models as a tool for valuation of shares in condition of global market
}

\author{
Jan Chutka $^{1, *}$, Katarina Kramarova ${ }^{2}$ \\ ${ }^{1}$ University of Zilina, Faculty of Operation and Economics of Transport and Communications, \\ Department of Economics, Univerzitna 1, 01026 Zilina, Slovak Republic \\ ${ }^{2}$ University of Zilina, Faculty of Operation and Economics of Transport and Communications, \\ Department of Economics, Univerzitna 1, 01026 Zilina, Slovak Republic
}

\begin{abstract}
With the rapid development of computational technology, nontraditional mathematical and statistical methods have also parallely developed to help simplify and accelerate the computation of certain tasks, or even to solve problems that are usually unsolvable. The aim of this paper is to get closer to the P/E earning models and briefly summarize their calculation and usage options. In the first part of our paper we briefly worked out the theoretical basis of these models. Furthermore, we focused on a detailed description of their calculation and use in calculating the value of shares. In the second part of the work we focused on the application of the calculation of the selected P / E model to Apple inc. in the course of 2018 and compared the data obtained with another instrument to identify the intrinsic value of the action. In the last part we focused on the interpretation and summary of the results of the application. We consider the greatest added value of our contribution to be a theoretical comparison of different types of calculation and deeper application of the selected model to real market prices of Apple inc. with the interpretation of the results obtained. We can conclude that the aim we have set is met and we believe that our article will be a valuable addition to the issue in this area.
\end{abstract}

\section{Introduction}

Determining intrinsic values through profit models is one of the most widely used methods among analysts. Our work deals with the calculation of $\mathrm{P} / \mathrm{E}$ ratio and its use in the analysis of shares selected by Apple inc.. These models do not result from anticipated dividends as dividend discount models, but are based on the size of the anticipated profit of the qualifying equity issuer attributable to the ordinary share. The aim of this paper is to get closer to the $\mathrm{P} / \mathrm{E}$ earning models and briefly summarize their calculation and usage options. The first part of the article deals with the $\mathrm{P} / \mathrm{E}$ model. We have elaborated various types of $\mathrm{P} / \mathrm{E}$ models in detail with their quantification procedures. In the second part of the paper

\footnotetext{
* Corresponding author: jan.chutka@fpedas.uniza.sk
} 
we focused on the application of selected P / E model calculation to Apple inc.. In the last part we focused on the interpretation and summary of the results of the application.

\section{Methodology}

In general, intrinsic values are used to determine whether assets are properly valued, undervalued or overvalued. In the event of an undervaluation, the asset is sold at a lower value and investors should buy the asset at that time. If the assets are overvalued, this is an inverse example of undervaluation and is a signal for sale. The constructional nature of profit models is based on the structure of the price earnings ratio. Most of the most commonly used types of profit models are derived from dividend discount models. This results in their close interdependence and similar calculation procedure. In investment practice, profit models are used rather than discount dividend models, which are used more in theory than in practice. Another difference between the two intrinsic value models is that profit models focus on shorter investment horizons but maximum 3 years [12]. In general, the value of $\mathrm{P} / \mathrm{E}$ ratio tells us how many times the investor appreciates the stock, respectively how many monetary units an investor is able to sacrifice for one monetary unit of the profit generated by the company that issued the share issue. Lists several types of P / E ratio models in her stock market analysis: historical, common, regression, Sharp and normal. The appropriate type of calculation of $\mathrm{P} / \mathrm{E}$ ratio we choose according to the type of stock exchange, respectively market price and according to the type of profit is applied in the calculations. All these types of $\mathrm{P} / \mathrm{E}$ ratios have different informative ability, usage, calculation method and input information therefore it is important to distinguish which one is appropriate to use $[1,5,13]$.

\subsection{Historical P/E}

For the calculation of the historical P / E, historical information on the market price of shares and profits per share, respectively, is used. We use information that has been common in history. Due to the high volatility and the resulting limited information, historical models do not operate with the historical $\mathrm{P} / \mathrm{E}$ ratio. The application of the historical $\mathrm{P} / \mathrm{E}$ ratio has only an ancillary position in the evaluation process, as the result is always indicative in nature. Historical information about the market price of shares and profits per share, respectively, is used for its calculation. We use information that has been common in history. Due to the high volatility and the resulting limited information, historical models do not operate with the historical $\mathrm{P} / \mathrm{E}$ ratio. The application of the historical $\mathrm{P} / \mathrm{E}$ ratio has only an ancillary position in the evaluation process, as the result is always indicative in nature.

\subsection{Common P/E}

The current $\mathrm{P} / \mathrm{E}$ is the result of the current exchange rate from the last published exchange rate list and from the current profit per share. As a primary indication of the attractiveness of an asset to an investor, it is a common $\mathrm{P} / \mathrm{E}$ ratio. This indicator is irreplaceable in the process of valuation of an asset due to its multiple use.

\subsection{Sharp P/E}

Sharp's P / E is based on Gordon's model. The result is expressed relative to the normal P / $\mathrm{E}$ ratio. The Sharp $\mathrm{P} / \mathrm{E}$ ratio is based on the normal values used in the normal $\mathrm{P} / \mathrm{E}$ ratio. If Sharp's $\mathrm{P} / \mathrm{E}$ is greater than the normal $\mathrm{P} / \mathrm{E}$, it is an undervalued asset or vice versa. If the value of the current $\mathrm{P} / \mathrm{E}$ and Sharp's $\mathrm{P} / \mathrm{E}$ is equal, this indicates an ideally rated asset [3]. 


\subsection{Regression P/E}

Regression P / E is a variation of Gordon's model. The primary rule is to clarify the intrinsic value of an asset as an adequate function $\mathrm{f}$ of a grouping of explanatory variables $\mathrm{X}$. Explaining variables may be: risk, quality of management, annual growth rate, dividend yield, equity, dividend per share, share yield, earnings per share and below. Regression P / $\mathrm{E}$ is the result of multiple regression. In the calculation he works with three independent variables, namely the rate of profit growth, risk and dividend pay-out ratio. In 1963, this model was known as the Whitbeck-Kisor regression equation. The result of the $\mathrm{P} / \mathrm{E}$ ratio regression model is reported in relative units. As in the Sharp model, the result of the overestimation and underestimation of a given asset is found with a comparison from the normal P / E ratio in the same terms as the Sharp P / E model. One of the problems critics point to in this model is the considerable correlation between the independent variables found in the equation. Considerable correlation arises between the risk and the rate of profit growth, as the rate of risk usually increases as profit increases $[3,8,9]$.

\subsection{Normal P/E}

Like previous models, this model was derived from Gordon's model, respectively, singlestage discount model. Based on the results, we can assess whether the asset is overstated or undervalued. If the result is higher than the market price of the share, the asset is undervalued and we can expect a possible exchange rate closer to the intrinsic value, and if the result is that the asset is overvalued, we can expect the exact opposite. This P / E model is very popular with analysts and comes second after the regular $\mathrm{P} / \mathrm{E}$ ratio model, which is usually displayed on the exchange rate list $[11,13]$.

Normal P / E quantification algorithm [13]:

$$
(P / E)_{N}=P_{0} / E_{0}=\frac{p}{k-g}
$$

$\mathrm{P} / \mathrm{E}$ - normal $\mathrm{P} / \mathrm{E}$ ratio

$\mathrm{p}$ - dividend payout ratio

$\mathrm{k}$ - the required rate of return on the share

$\mathrm{g}$ - profit growth rate, respectively dividend growth rate

P0 - current market price (exchange rate) of a market share

E1 - expected profit next year

$$
V_{0}=(P / E)_{N} \times E_{1}
$$

V0 - intrinsic value of the asset [6]

\subsection{Advantages and disadvantages of P/E models}

Like any indicator, $\mathrm{P} / \mathrm{E}$ brings some problems. One of the main problems arises with negative or zero gain, where $\mathrm{P} / \mathrm{E}$ cannot be quantified. Although we can imagine a negative $\mathrm{P} / \mathrm{E}$, it is not used in practice or published with the rules. Therefore, if the $\mathrm{P} / \mathrm{E}$ indicator is not available in the enterprise under review and at the same time we have reported a loss, the reason for the unavailability of this indicator is obvious. However, this does not mean that any action that has no published $\mathrm{P} / \mathrm{E}$ is in negative or zero economic 
result, as the classical form of $\mathrm{P} / \mathrm{E}$ is based on profits for the last 1 year (full 12 months) and therefore unavailability of the $\mathrm{P} / \mathrm{E}$ value. It may be due to the fact that these shares have not been traded for 12 months. This is considered a significant disadvantage. Another case may be the shares of smaller companies in the biotechnology sector, which do not necessarily make a profit (unavailable P / E), but may nevertheless represent a very interesting investment opportunity $[4,10]$.

\subsection{Diversification of equities to properly priced and poorly priced based on $\mathrm{P} / \mathrm{E}$ ratio in relation to profit level and profit growth rate}

A very important part in evaluating the data obtained through the $\mathrm{P} / \mathrm{E}$ model is the interpretation of the obtained results. The following table shows diversification of equities to properly priced and poorly priced based on $\mathrm{P} / \mathrm{E}$ ratio in relation to profit level and profit growth rate.

Table 1. Advantages and disadvantages of $\mathrm{P} / \mathrm{E}$ models

\begin{tabular}{|l|l|}
\hline \multicolumn{1}{|c|}{ Advantages of P/E models } & \multicolumn{1}{c|}{ Disadvantages of P/E models } \\
\hline Simplicity of calculation & $\begin{array}{l}\text { P / E does not take into account the debt } \\
\text { financial structure }\end{array}$ \\
\hline Widely used & $\begin{array}{l}\text { Revenue is sensitive to management } \\
\text { manipulation }\end{array}$ \\
\hline It takes forecasts into account & $\begin{array}{l}\text { P/ E does not take into account cash } \\
\text { generation }\end{array}$ \\
\hline $\begin{array}{l}\text { Revenue is a measure of what is generated } \\
\text { for shareholders }\end{array}$ & $\begin{array}{l}\text { P / E presents difficulties in assessing } \\
\text { income quality }\end{array}$ \\
\hline
\end{tabular}

Table 2. Diversification of equities to properly priced and poorly priced based on P / E ratio

\begin{tabular}{|c|c|}
\hline Undervalued asset & $\begin{array}{l}\text { Correctly valued asset (with high yield } \\
\text { potential) }\end{array}$ \\
\hline High growth rate & High growth rate \\
\hline $\begin{array}{l}\text { Low P / E ratio (taking into account risk, } \\
\text { liquidity and other effects on } \mathrm{P} / \mathrm{E} \text { ) }\end{array}$ & $\begin{array}{l}\text { High value of } \mathrm{P} / \mathrm{E} \text { ratio (taking into } \\
\text { account risk, liquidity and other effects on } \mathrm{P} \\
\text { / E) }\end{array}$ \\
\hline Overvalued asset & $\begin{array}{c}\text { Correctly valued asset (with low yield } \\
\text { potential) }\end{array}$ \\
\hline Low growth rate & Low growth rate \\
\hline $\begin{array}{l}\text { High value of } \mathrm{P} / \mathrm{E} \text { ratio (taking into account } \\
\text { risk, liquidity and other effects on } \mathrm{P} / \mathrm{E} \text { ) }\end{array}$ & $\begin{array}{l}\text { Low } \mathrm{P} / \mathrm{E} \text { ratio (taking into account risk, } \\
\text { liquidity and other } \mathrm{P} / \mathrm{E} \text { effects) }\end{array}$ \\
\hline
\end{tabular}

\section{Results}

For the purposes of this paper, we conducted a comparison of the explanatory power of the $\mathrm{P} / \mathrm{E}$ model and the moving average. The comparison took place at the market prices of Apple Inc. over the course of 2018. On the basis of the daily price chart, we identified the points of intersection of the market price and the simple moving average. We then calculated the $\mathrm{P} / \mathrm{E}$ and the intrinsic value of the action at these location $[2,7,14]$. The measured data are as follows. 
Table 3. Diversification of equities to properly priced and poorly priced based on $\mathrm{P} / \mathrm{E}$ ratio

\begin{tabular}{|c|c|c|c|c|c|}
\hline Date & $\mathrm{P} / \mathrm{E}$ & EPS & Instrict value & SMA (9) & Market close price \\
\hline 31.12 .2017 & - & 9,73 & - & - & - \\
\hline 3.1 .2018 & 18,75 & - & 182,44 & 172,26 & 172,23 \\
\hline 10.1 .2018 & 18,97 & - & 184,58 & 172,87 & 174,29 \\
\hline 23.1 .2018 & 19,27 & - & 187,5 & 177,08 & 177,04 \\
\hline 12.2 .2018 & 16,84 & - & 163,85 & 161 & 162,71 \\
\hline 1.3 .2018 & 18,01 & - & 175,24 & 174,84 & 175 \\
\hline 13.3 .2018 & 18,32 & - & 178,25 & 178,38 & 178,02 \\
\hline 27.3 .2018 & 17,32 & - & 168,52 & 172,6 & 168,34 \\
\hline 31.3 .2018 & - & 10,36 & - & - & - \\
\hline 4.4 .2018 & 17,66 & - & 182,96 & 168,43 & 171,61 \\
\hline 19.4. 2018 & 17,74 & - & 183,79 & 174,37 & 172,8 \\
\hline 1.5 .2018 & 16,34 & - & 169,28 & 165,69 & 169,1 \\
\hline 15.5 .2018 & 18,01 & - & 186,58 & 185,83 & 186,44 \\
\hline 1.6 .2018 & 18,38 & - & 190,42 & 188,04 & 190,24 \\
\hline 13.6 .2018 & 18,43 & - & 190,93 & 192,08 & 190,7 \\
\hline 27.6 .2018 & 17,79 & - & 184,3 & 185,66 & 184,16 \\
\hline 30.6 .2018 & - & 11,03 & - & - & - \\
\hline 27.7 .2018 & 18,45 & - & 203,5 & 192,2 & 190,98 \\
\hline 13.8 .2018 & 20,18 & - & 222,59 & 207,29 & 208,87 \\
\hline 6.9 .2018 & 21,56 & - & 237,81 & 223,09 & 223,1 \\
\hline 24.9 .2018 & 21,33 & - & 235,27 & 220,48 & 220,79 \\
\hline 30.9 .2018 & - & 11,87 & - & - & - \\
\hline 9.10 .2018 & 21,92 & - & 260,19 & 226,91 & 226,87 \\
\hline 22.10 .2018 & 21,32 & - & 253,07 & 218,84 & 220,65 \\
\hline 1.11 .2018 & 21,47 & - & 254,85 & 217,9 & 222,22 \\
\hline 28.11 .2018 & 17,48 & - & 207,49 & 180,74 & 180,94 \\
\hline 4.12 .2018 & 17,07 & - & 202,62 & 177,01 & 176,69 \\
\hline 28.12 .2018 & 15,09 & - & 179,12 & 157,9 & 156,23 \\
\hline
\end{tabular}

\section{Discussion}

Overall, we identified 24 situations in the market in a single horizon of one calendar year, when a simple moving average and APPL stock price clashed. Subsequent comparison of the moving average with the closing rate of the action and following the evolution of the intrinsic value as a special and correctly valued action led to the following conclusions. The 
nine-day simple moving average in 17 situations out of the 24 measured gave us unambiguous and truthful information about further price developments. Of the 17 situations, 9 were consistent with the $\mathrm{P} / \mathrm{E}$ ratio, which is more than half. In the remaining 7 measured data, it sent out false signals, mostly shopping, in the last three months. Based on the calculated intrinsic value of the share through the $\mathrm{P} / \mathrm{E}$ ratio, we found that the share was undervalued throughout the period. In the first half of the year, the internal stock price fluctuated around the market rate, with a maximum difference of approximately $\$ 10$. In the second half it was much higher and about $\$ 30$, which for shareholders means a considerable loss. For a better idea of the differences we can see in graph no. 1. Since the stock was undervalued all year long, we did not compare the P / E ratio based on the results of a fundamental analysis telling us about the overvaluation and undervaluation of the stock, but what a proper-valued stock would look like and the results compared to the moving average.

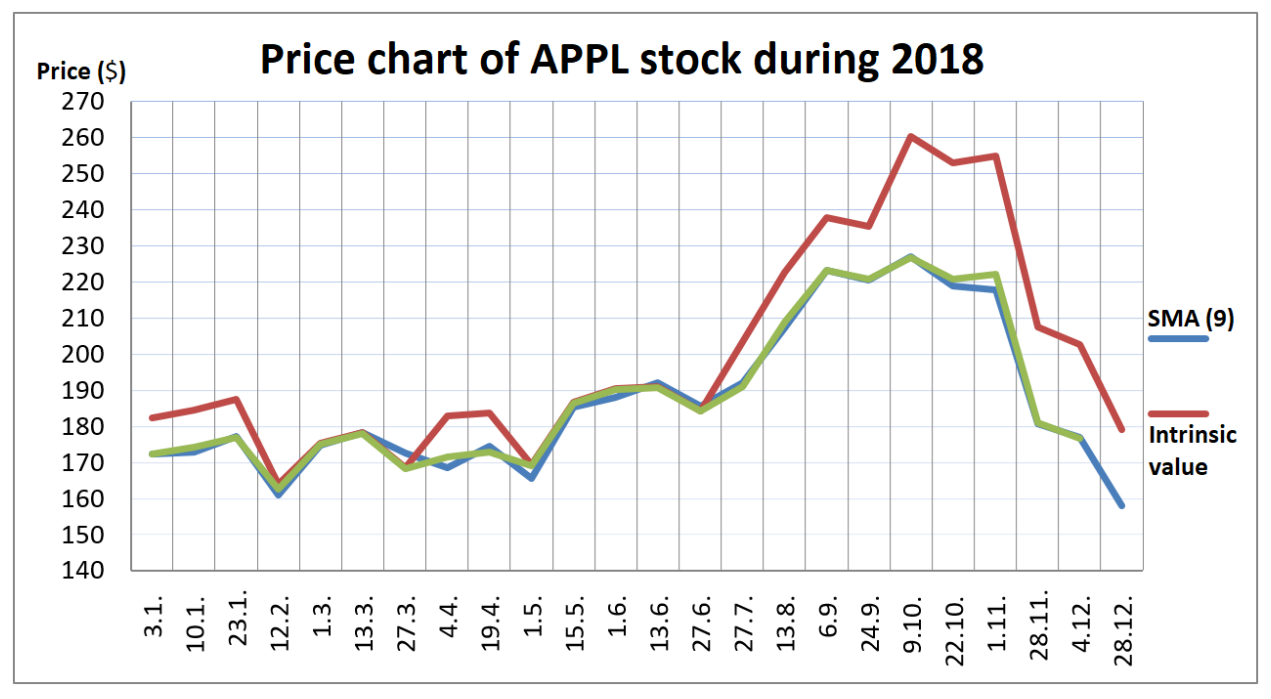

Fig. 1. Comparison of SMA(9) and intrinsic value of APPL stock price during 2018

Compared to the moving average of 24 situations, the $\mathrm{P} / \mathrm{E}$ ratio model was successful in predicting further developments in 14 cases, representing a $58.33 \%$ success rate in profitmaking investment. The low success rate may be due to the fact that fundamental analysis is oriented to long-term predictions, but nevertheless its success is not among the lowest values. In the last quarter, we also noticed three situations where both the $\mathrm{P} / \mathrm{E}$ ratio and the moving average failed. Based on the summary results for the investor, we can recommend some kind of optimization, thanks to which his profits will increase losses caused by false signals decrease. It would be much more advantageous for the investor, according to the results, to use a simple moving average along with the $\mathrm{P} / \mathrm{E}$ ratio model, ie. because of the better testimony and decision-making ability they bring. We came to the following conclusion by calculating the probability of successful trading by individual indicators. Separately, the $\mathrm{P} / \mathrm{E}$ ratio was $58 \%$ and the moving average was $70 \%$ successful. On the other hand, if we only traded if the resulting moving average predictions and the $\mathrm{P} / \mathrm{E}$ ratio match, we would make only 9 trades out of a total of 24 situations, but in each of the 9 trades the market did not send a false signal, ie. that the market developed $100 \%$ according to the results. For the investor this means the possibility to determine a true prediction of 
market development and according to the results t. j. either buy stocks or sell them. According to the above, he is able to determine whether the given trend, which applies to a given stock, but also another asset will continue or change direction. There may also be situations where the combination of a simple moving average and the $\mathrm{P} / \mathrm{E}$ ratio model would not provide a clear signal to buy or sell, in which case we could recommend using one of the moving average modifications, e.g. exponential or linear moving average, if necessary adjust the number of days, respectively value " $n "$ in the calculation. If the investor is not able to make a smaller number of trades in a given period, we could recommend him to choose one more indicator from the technical analysis due to their shortterm orientation and compare the results of both indicators with another indicator and decide on the final comparison of results.

\section{Conclusion}

Earnings management is one of the most provocative topics in accounting and finance [15, 16]. The title implies that it is a profit that, for users of financial statements, is a source of valuable information for their future decisions. However, the information value of profit becomes questionable when we realize that business managers not only have the motivation, but also the ability to apply their own judgment and subjective estimates to compile their financial statements, what to do to meet their own needs or business needs and it leads to opportunistic management of reported earnings. The aim of this paper was to get closer to the $\mathrm{P} / \mathrm{E}$ earning models and briefly summarize their calculation and usage options. The first part of the article deals with the P / E model. We have elaborated various types of P / E models in detail with their quantification procedures. In the second part for the purposes of this paper, we conducted a comparison of the explanatory power of the $\mathrm{P} /$ E model and the moving average. The comparison took place at the market prices of Apple Inc. over the course of 2018. On the basis of the daily price chart, we identified the points of intersection of the market price and the simple moving average. We then calculated the $\mathrm{P}$ / $\mathrm{E}$ and the intrinsic value of the action at these locations. In the last part we focused on the interpretation and summary of the results of the application.

The paper is an output of the science project VEGA 1/0210/19 Research of innovative attributes of quantitative and qualitative fundaments of the opportunistic earnings modelling.

\section{References}

1. P. Adamko, E. Spuchlakova, K. Valaskova, The history and ideas behind VaR. Procedia Economics and Finance 24, 18-24. (2015)

2. A. P. Balcerzak, T. Kliestik, D. Streimikiene, L. Smrcka, Non-parametric approach to measuring the efficiency of banking sectors in European Union countries. Acta Polytechnica Hungarica 14, 51-70. (2018)

3. S. Cisko, T. Kliestik, Financial Management I. Zilina: EDIS - publishing ZU in Zilina. 353-354 s. ISBN 978-80-554-0076-1. (2009)

4. F. Fiordelisi, G. Galloppo, Stock market reaction to policy interventions. In The European Journal of Finance 24, 1817-1834. (2018)

5. D. Hraskova, V. Bartosova, Emergent approach to management of the transport company. Advances in Social and Behavioral Sciences 5, 92-96. (2014)

6. B. Chovancova, V. Malacka, V. Demjan, J. Kotlebova, Financial markets Instruments and transactions. Bratislava: Wolters Kluwer, s. r. o. ISBN 978-80-8168-006-9. (2014) 
7. J. Kaur, D. Kaur, Application of moving averages: An empirical study of selected commodity future indices. Indian Journal of Economics and Development 13, 496-501. (2017)

8. A. Kasych, M. Vochozka, The choice of methodological approaches to the estimation of enterprise value in terms of management system goals. Quality - Access to Success 20, 3-9. (2019)

9. P. Kral, K. Janoskova, Condition of acceptability of project risk in management of the project portfolio, 15th International Scientific Conference on Globalization and its Socio-Economic Consequences, Rajecke Teplice, 345-352. (2015)

10. P. Kristofik, J. Horak, P. Suler, Provision of trade credits in relation to corporate payment ability: A case study of the Visegrad four. Ekonomicko-manazerske spektrum 13, 96-108. (2019)

11. Ch. Ma, D. Wen, G. J. Wang. Further mining the predictability of moving averages: Evidence from the US stock market. International Review of Finance 19, 413-433. (2019)

12. O. Rejnus, Financial Markets 4th, updated and expanded edition. Prague: Grada Publishing a. s. ISBN 978-80-274-367-6. (2014)

13. J. Vesela, Analysis of the securities market II. part: fundamental analysis. Prague: University of Economics, Prague. ISBN 80-245-0506-1. (2003)

14. V. Zakamulin, Revisiting the profitability of market timing with moving averages. International Review of Finance 18, 317-327. (2018)

15. A. Krizanova, L. Stefanikova, G. Masarova, Key success factors of company's intelligence program. In 8th International Scientific Conference on Business and Management (Vilnius, Lithuania, 85-92, 2014)

16. W. Sroka, J. Cygler, B. Gajdzik, The Transfer of Knowledge in Intra-Organizational Networks: A Case Study Analysis. Organizacija 47, 1, 24-34 (2014) 